\title{
Geometric Mosaics from the Courtyard of the Great Bath at Antiochia ad Cragum in Western Rough Cilica
}

\author{
Batı Dağlık Kilikya Bölgesi Antiochia ad Cragum Kenti Büyük \\ Hamam Yapısı Havuzlu Avlu Mekanı'nın Geometrik Mozaikleri
}

Birol CAN*

(Received 03 October 2016, accepted after revision 20 June 2017)

\begin{abstract}
The original floors of the courtyard and room with apse (frigidarium?), recently uncovered at the Great Bath Complex in Antiochia ad Cragum, one of the better preserved structures of the ancient city located along the Mediterranean coast of western Rough Cilicia, are covered with mosaics. Only a few fragments of the room with apse mosaic have been preserved, but the courtyard mosaic has remained largely intact. These mosaics, consisting of panels and borders, contain a wide variety of geometric motifs. The geometrical patterns seen here have been encountered in Roman mosaics throughout the entire Mediterranean basin from the Middle East to the Iberian Peninsula. However, in terms of motif and technique, the closest similar examples of this third century AD mosaic of the courtyard can be found in Anatolia, including in particular the region of Cilicia.
\end{abstract}

Keywords: Rough Cilicia, Antiochia ad Cragum, bath, mosaic, geometric.

$\ddot{\mathrm{O} z}$

Batı Dağlık Kilikya bölgesinin kıyı kenti Antiochia ad Cragum'un en sağlam yapılarından biri olan Büyük Hamam kompleksinin şu ana kadar açılan havuzlu avlu ve apsisli mekan (frigidarium?) bölümlerinin zeminleri mozaik döşsemeyle kaplıdır. Apsisli mekan mozaiklerinin çok azı korunabilmiștir, havuzlu avlu mozaikleri ise büyük ölçüde sağlam kalabilmiştir. Panolar ve bordürlerden oluşan bu mozaikler çok çeşitli geometrik repertuara sahiptir. Burada görülen geometrik örüntülerle, Ortadoğu'dan İber Yarımadası'na kadar tüm Akdeniz havzası içindeki Roma dönemi mozaiklerinde karşılaşıllr. Bununla birlikte, IS 3. yüzyıla tarihli havuzlu avlu mozaiklerinin hem motif, hem teknik açıdan en yakın benzerlerine başta Kilikya bölgesi olmak üzere Anadolu'da rastlamak mümkündür.

Anahtar Kelimeler: Dağlık Kilikya, Antiochia ad Cragum, hamam, mozaik, geometrik.

\section{Introduction}

Antiochia ad Cragum is located on Turkey's southern shoreline, in the western mountainous parts of Cilicia, also known in Antiquity as Rough Cilicia (Fig. 1). In the late Hellenistic period, it is known to have been the most important haven of pirates until a Roman fleet lead by Pompey the Great defeated them at Korakesion in 67 BC (Hoff et al. 2014a: 66-67). Antiochos IV of Commagene, who reigned in the region from 38 to $42 \mathrm{AD}$ as a client king to the Roman Empire, founded an eponymously-named city here. Later this city became part of the Roman Province of

\footnotetext{
* Birol Can, Uşak University, Faculty of Arts and Sciences, Department of Archaeology, Uşak, Türkiye.

E-mail: birol.can@usak.edu.tr

I would like to thank Prof. Michael C. Hoff, director of Antiochia ad Cragum excavations for allowing me to work on the mosaics.
} 


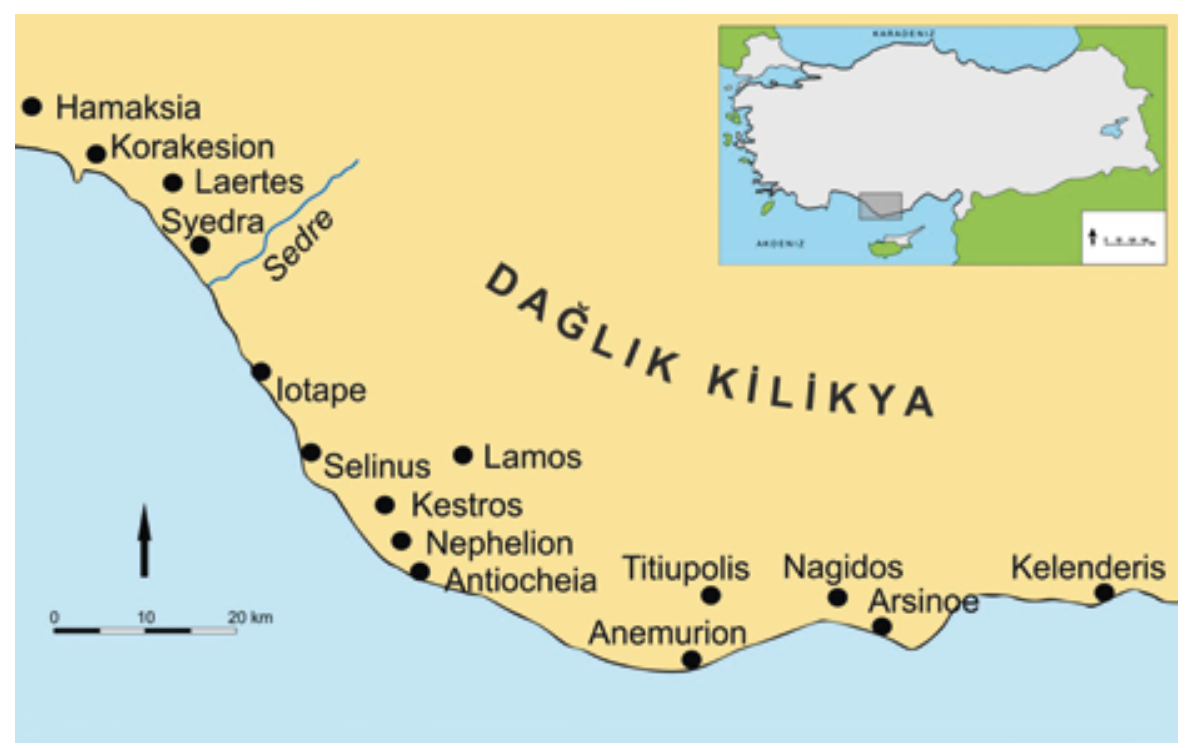

Cilicia. It is situated on terraces on steep slopes overlooking the Mediterranean Sea (Hoff-Can 2013: 49-50; Can-Hoff 2014: 374-375; Hoff et al. 2015a: 203).

As in many other Roman Cilician cities, numerous mosaics have been found in Antiochia ad Cragum. Its Great Bath complex has attracted attention with an array of geometrical mosaics decorating its floors since its excavation that began in 2012 (Hoff et al. 2014b: 10-12) (Fig. 2). The Great Bath complex is located in the city centre on a wide terrace approximately 336 meters above sea level, amongst other public buildings such as the Colonnaded Street and the Bouleuterion. Of all the buildings in the city, the Great Bath has survived the most intact and the floors of the "Courtyard" and the "Room with Apse (Frigidarium?)" are covered with mosaics. Despite the partial damage, the geometrical designs can be clearly recognised. As yet, other areas of the Bath, including the tepidarium and caldarium, spanning approximately $1500 \mathrm{~m}^{2}$ have not been excavated.

The rectangle courtyard, measuring $24.50 \times 14.50 \mathrm{~m}$, is located on the east side of the Bath complex (Hoff et al. 2013a: 158-161; Hoff et al. 2013b: 470-471; Can - Hoff 2014: 379; Hoff et al. 2014a: 71; Hoff et al. 2015a: 212-217) (Fig. $3)$. Two niches, intended for statues, at a height of $2.20 \mathrm{~m}$ on its relatively intact western wall, have been partially preserved. A statue of Asklepios, dedicated by the sons of Sourbios, is mentioned on an inscription found in-situ under one of these niches. There are eight doors that lead to the courtyard from the outside, as well as from the other rooms of the Bath. The swimming pool (natatio) with apsidal ends situated in the centre of the courtyard is $11.53 \mathrm{~m}$ long, $4.82 \mathrm{~m}$ wide and $1.03 \mathrm{~m}$ deep. The inside is surrounded by a single step, while access to the pool is provided by massive single stepping stone blocks on either end. The pool is lined with marble blocks and the floor is paved with limestone pavers and some spolia. It is sloped slightly towards the north. The filling and emptying of the pool was done via lead pipes. Fourteen square-shaped stone bases supported columns carrying the ceiling of the courtyard. Evidence suggests that the wooden columns that rested on these bases were supporting an inclined roof. Excavations inside the pool uncovered numerous terracotta roof tiles. Although the roof covered the four sides of the room, there was an opening in the ceiling above the pool.
Figure 1

Rough Cilicia and

Antiochia ad Cragum.
Figure 2

Antiochia ad Cragum, Greath Bath Complex (right page, top).

Figure 3 Great Bath, courtyard (right page, bottom). 

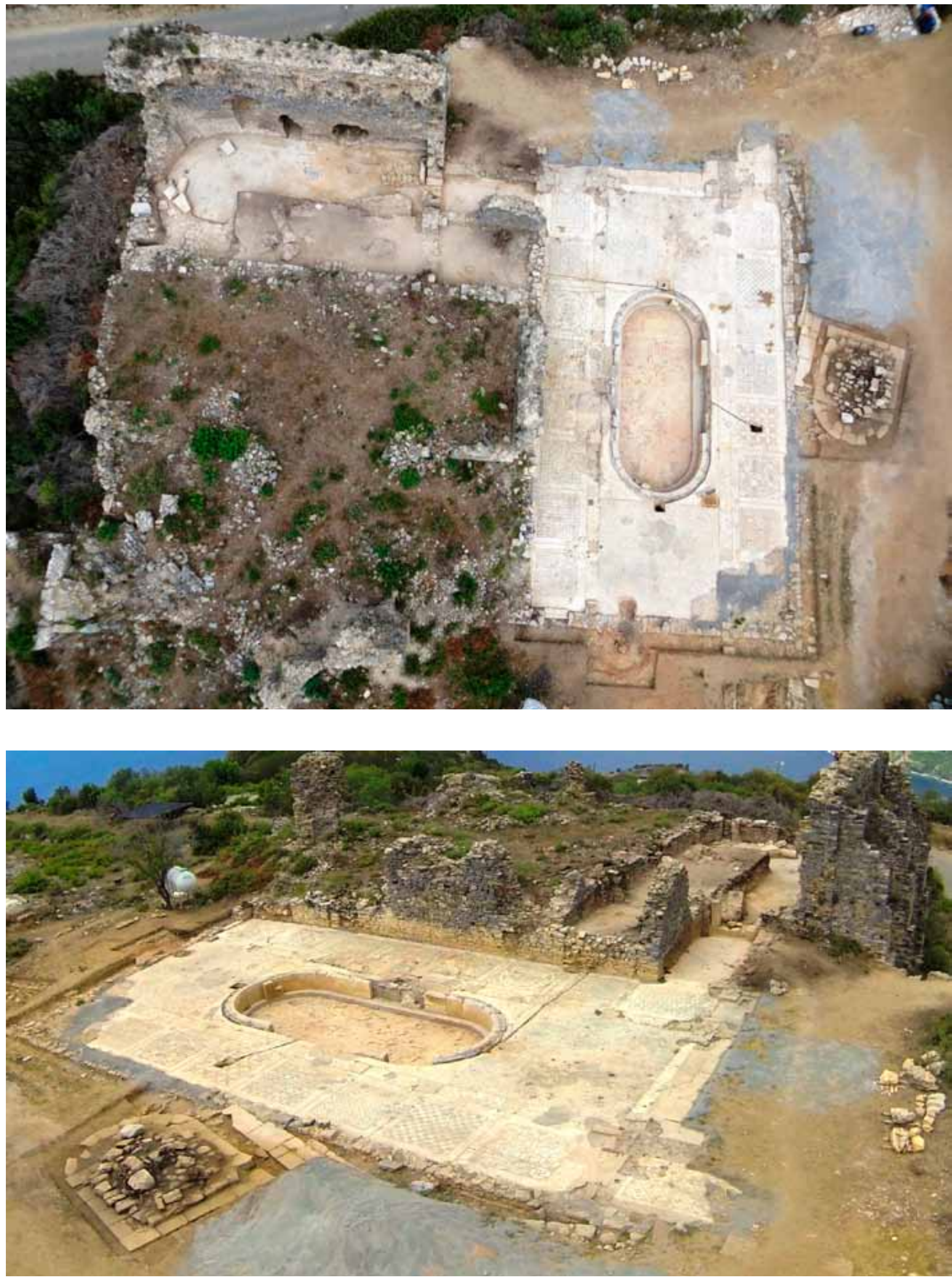


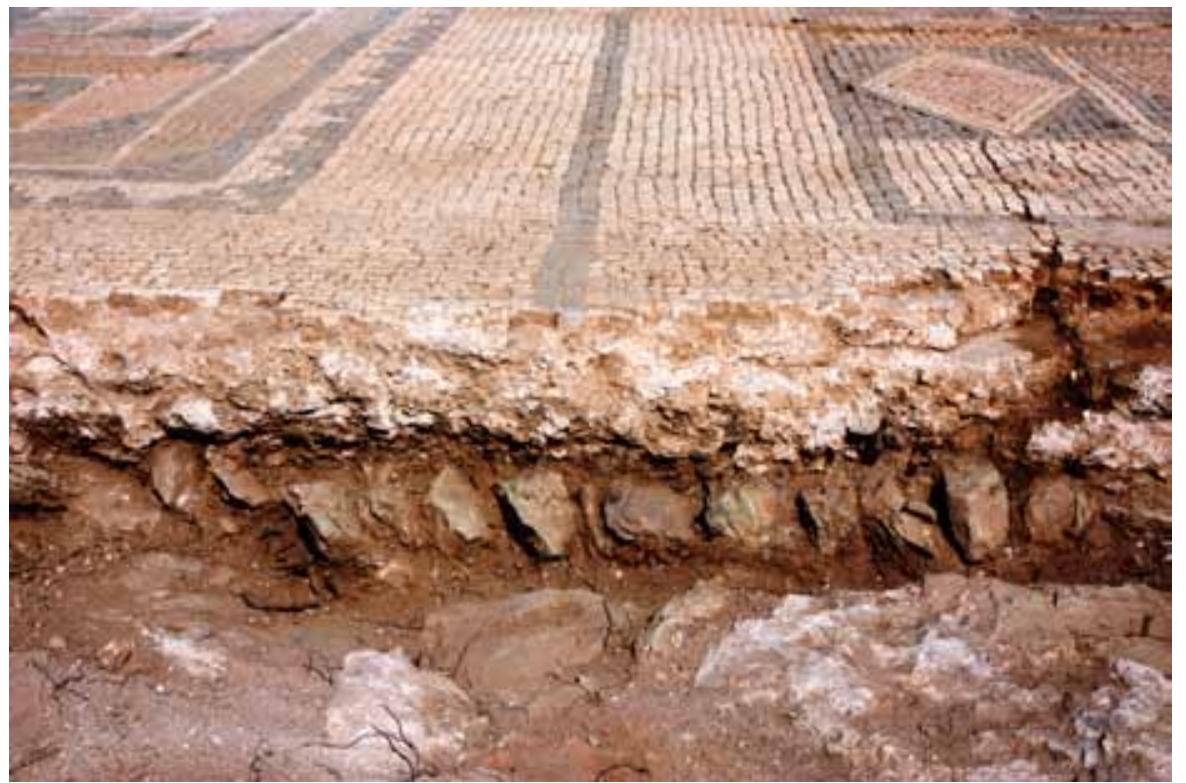

The entirety of the floor in the courtyard, apart from the pool, was decorated with mosaics. Three drains in the flooring connect to the waste water channel system grid running underneath the floor. The channel also connects with the other parts of the Bath before the waste water is discharged from the building. These channels are covered with big flat stone slabs (Can - Hoff 2014: 380-381; Can et al. 2015: 2-3; Hoff et al. 2015b: 583; Can et al. 2016: 80).

The mosaics covering the courtyard floor have obviously been placed on a robust foundation (Fig. 4). The lowermost, a thick and solid mortar layer, is followed by the statumen, consisting of rough stones of various sizes, placed in an upright position and above the statumen is a rudus layer 6 to $8 \mathrm{~cm}$ thick with a relatively coarse mortar. On this sturdy rudus layer it is possible to see the incised lines for the layout of the mosaic panels. Covering these is a nucleus layer with a thickness of approximately $6 \mathrm{~cm}$ that consists of a finer mortar composition. On the very top a fine setting-bed fixes the tesselatum. The colours of the tesserae used in the courtyard mosaics are various tones of grey, white, pink, yellow, red and brown. The sizes of the tesserae slightly vary inside and outside the panels and are cut in different shapes according to the design of the mosaic. The dimensions of unevenly cut tesserae range from $1.5 \mathrm{~cm}^{3}$ to $3 \mathrm{~cm}^{3}$ and similarly the average number of tesserae per square-meter also changes, albeit slightly. Counts conducted at several areas in the room showed an average of 20 to 25 tesserae per $10 \mathrm{~cm}^{2}$. Therefore, on average one tessera measures approximately $2 \mathrm{~cm}^{3}$. The tesserae of the mosaics on the floors of the north-eastern and north-western small entrances are slightly larger. In these zones, about 15 tesserae of about $2.5 \mathrm{~cm}^{3}$ are counted per $10 \mathrm{~cm}^{2}$.

Since the building was used for other purposes after the Bath fell into disuse, the mosaics have been partially damaged. By digging until the bedrock was reached, a glass furnace with a diameter of $3,00 \mathrm{~m}$ and a depth of $0.70 \mathrm{~m}$ was built at about the middle of the southern wall of the courtyard in Late Antiquity (CanHoff 2014: 381; Can et al. 2015: 3; Hoff et al. 2015b: 584). The construction of this furnace damaged the wall as well as the mosaics. Traces of fire observed on the mosaics in this section of the room are a consequence of glass production. Additionally, in Late Antiquity a kiln for amphora production was installed in the southeast corner of the room with apse. Mosaics in the area where this 


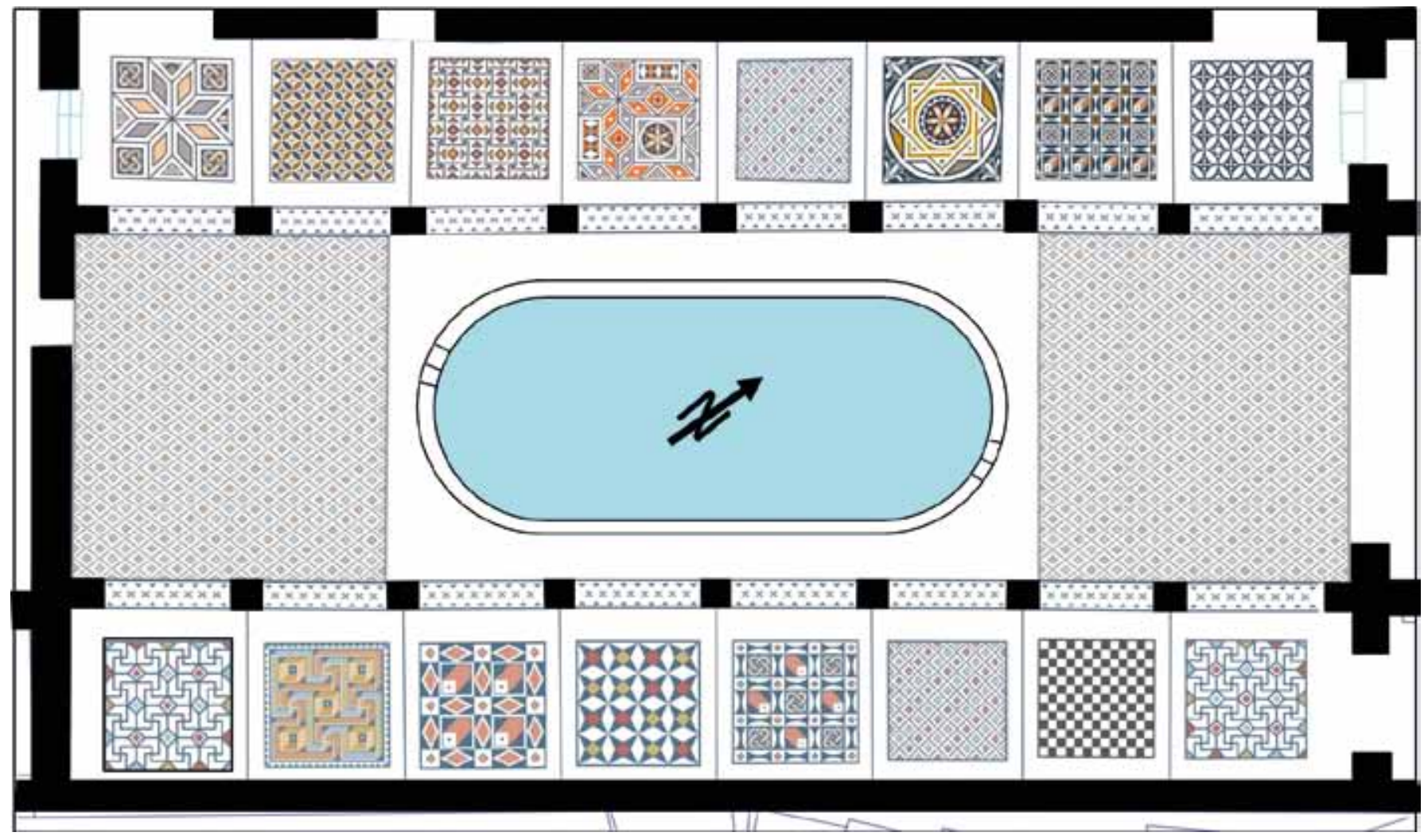

Figure 5

The principal layout of the courtyard mosaics. circular kiln was discovered show extensive damage and sections which have survived show indications of fire damage. Another cause of damage to the mosaics is vegetation. In time roots caused ripples and swelling and created cavities under the mosaics and even reached the rudus layer in some places.

For now mosaic conservators have carried out provisional restorations. By filling the lacunae with mortar consisting of brick dust, fine sand and lime paste, the tesserae were prevented from deteriorating. Roots, occurring especially on the courtyard mosaics, were removed. At present the mosaics are being protected by geotextile fabric covers and river sand. After excavations at the Bath are concluded, a roof will be installed to protect the site and the mosaics will be restored entirely and open to public view.

The principal layout of the courtyard mosaics consists of borders on a white background surrounding square panels (Fig. 5). Each of the 16 square panels on the east and west sides of the pool measures $2.30 \times 2.30 \mathrm{~m}$ and contain very colourful geometrical and stylised floral patterns. Panel E1, the northernmost of the eight panels on the east side of the swimming pool, depicts intricate linear bands forming swastika motifs by their intersections (Dunbabin 1999: 295340 fig. 300-I) (Fig. 6). The spaces between are decorated with colourful and concentric equilateral lozenge motifs which are also connected to each other via linear bands. A similar layout is known from a mosaic from Antakya-Harbiye where in contrast the lozenges in the spaces are elongated (Çelik 2008: 30-31). The geometric design of Panel E2 consists of light and dark colours in a checkerboard pattern (Fig. 7). This pattern was widely used in early periods (Ovadiah 1980: 129-130; Ling 1998: fig. 82 "Spain, Roman Villa, Ampurias", fig. 83 "Britain, Roman Villa at Brading"; Salman 2007: 229-230 fig. 168 "Adiyaman Museum"; Houix et al. 2011: fig. 4 "France, A Roman House in Nimes"; Omari 2011: fig. 7 "Albania, Durres"; Abraços 2014: figs. 2-3 "Portugal, Archaeology Museum D. 

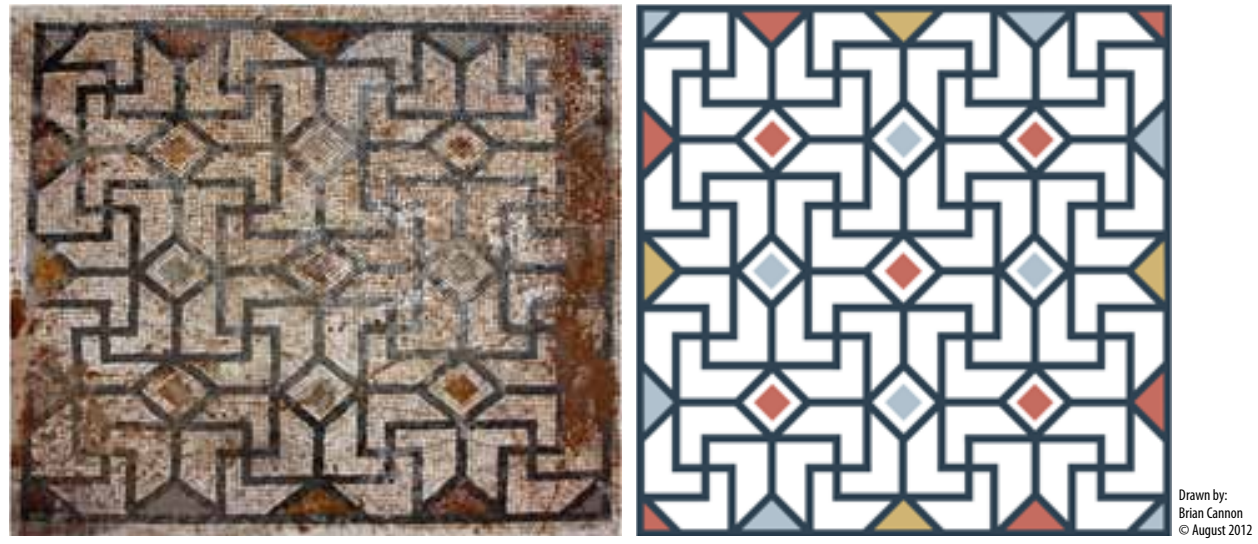

Figure 6

The panel E1.
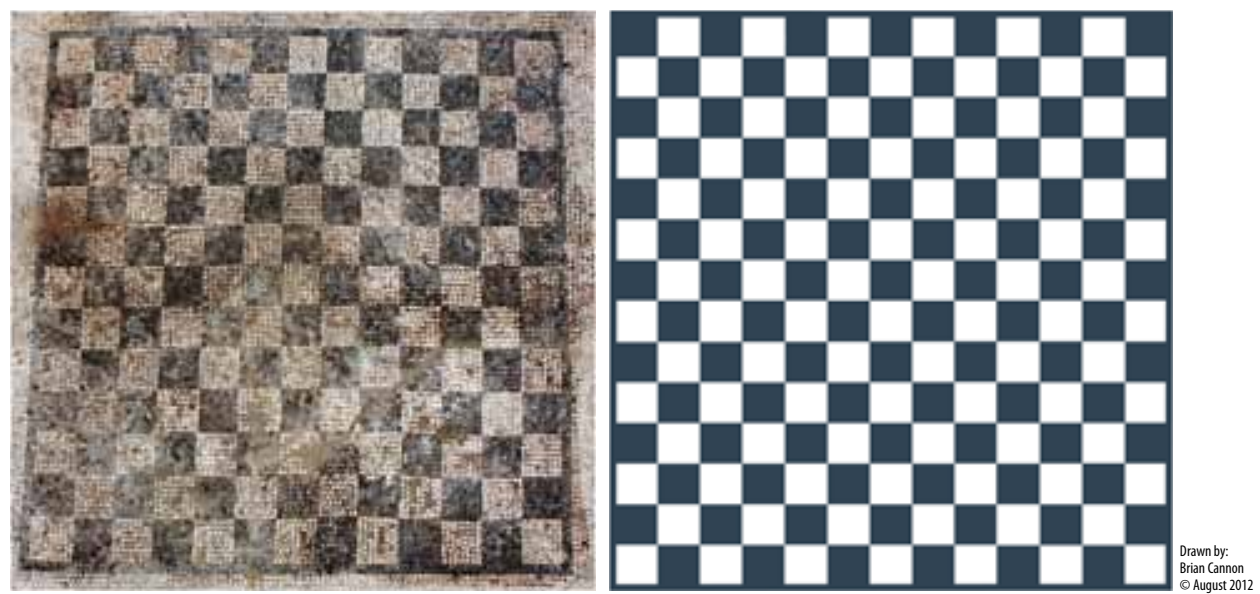

Figure 7

The panel E2.
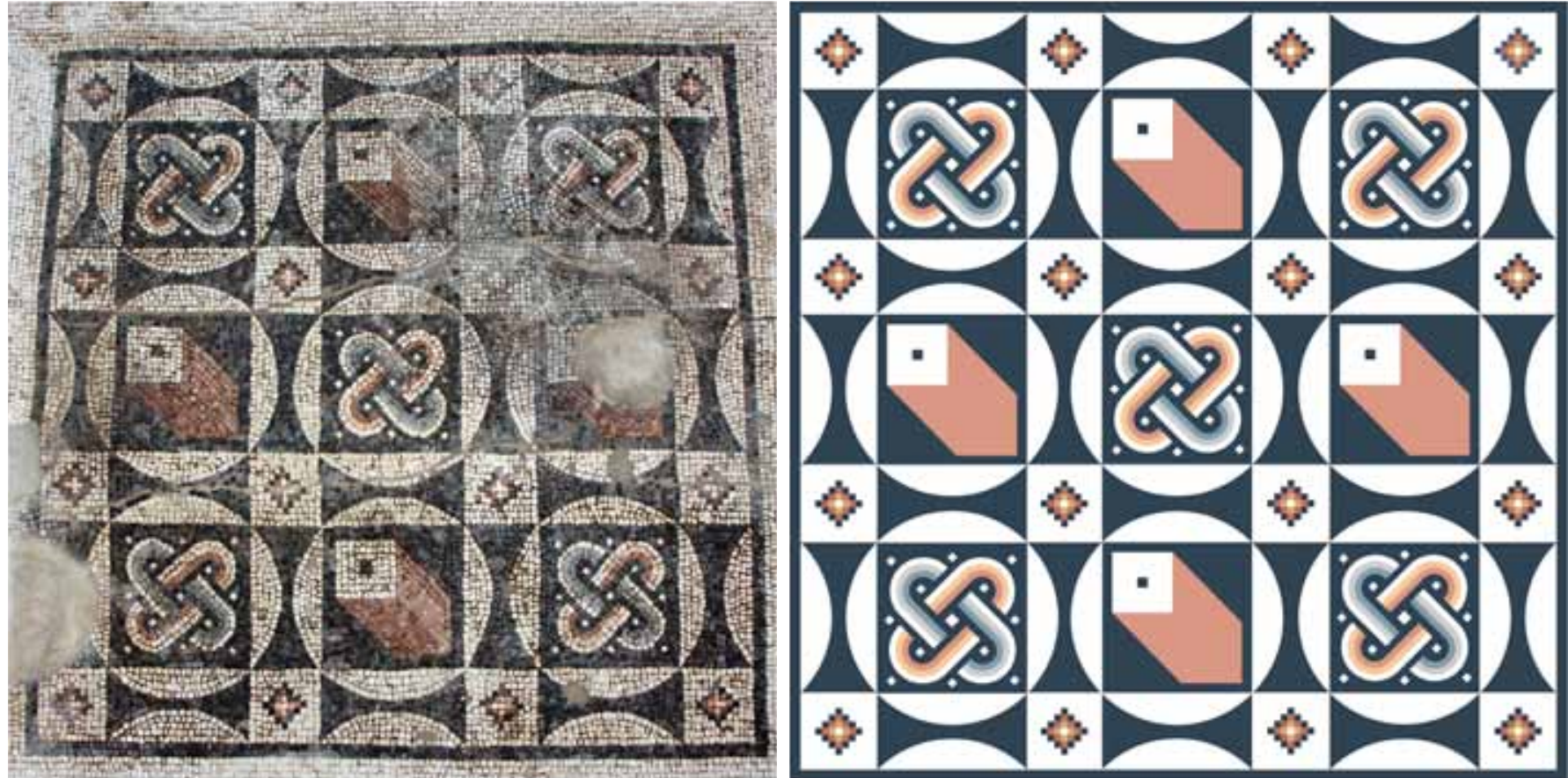

Diogo de Sousa"), although examples are also found in Late Antiquity (Patac1 2011: fig. 3 "Paphlagonia Hadrianoupolis, Bath A"). The decoration in Panel E3 contains concentric equilateral diamond shapes lined up in a diagonal fashion The panel E3.

(Fig. 8). In Panel E4 we see multicoloured concentric circles and squares (Fig. 9). Inside the larger squares are Solomon's knot motifs and three-dimensional 

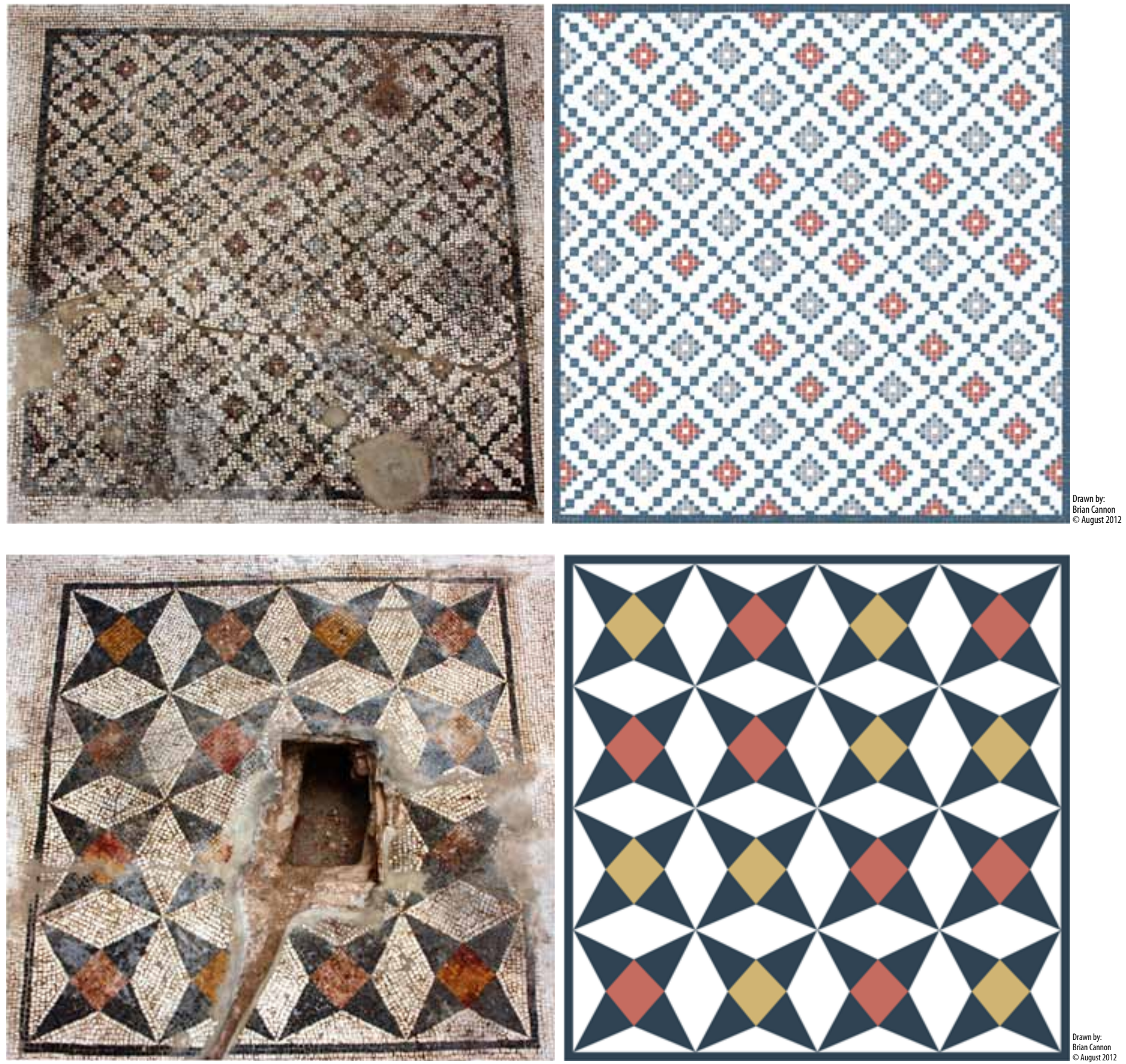

Figure 9

The panel E4.

Figure 10

The panel E5. patterns. In the smaller square-shaped spaces in between, we see multicoloured concentric diamonds. Similar patterns are known from mosaics dating to Late Antiquity (Jobst 2011: fig. 44 "Lesbos, Basilica of Skala Eressos", fig. 45 "Ephesos, Basilica"). Panel E5 depicts four-pointed stars with their tips touching each other (Fig. 10). The centres of these stars form colourful equilateral diamonds. A very similar arrangement can be seen in the design of the Europa mosaic dating to the second century AD from Emerita Augusta in Spain. This motif is also present in mosaics dating to the second and third centuries AD in Cilicia and surrounding regions (Cimok 2000: 50-53 "Antioch, House of Drunken Dionysos", 178 "Antioch, Narcissus Mosaic, House of Menander"; Tülek 2005: fig. 25.4 "Alanya Museum”, fig. 36.10-11, 14-15 "Silifke”; Ergeç 2006: 54-57 “Zeugma, Roman Bath-Gymnasium Complex”; Salman 2007: 

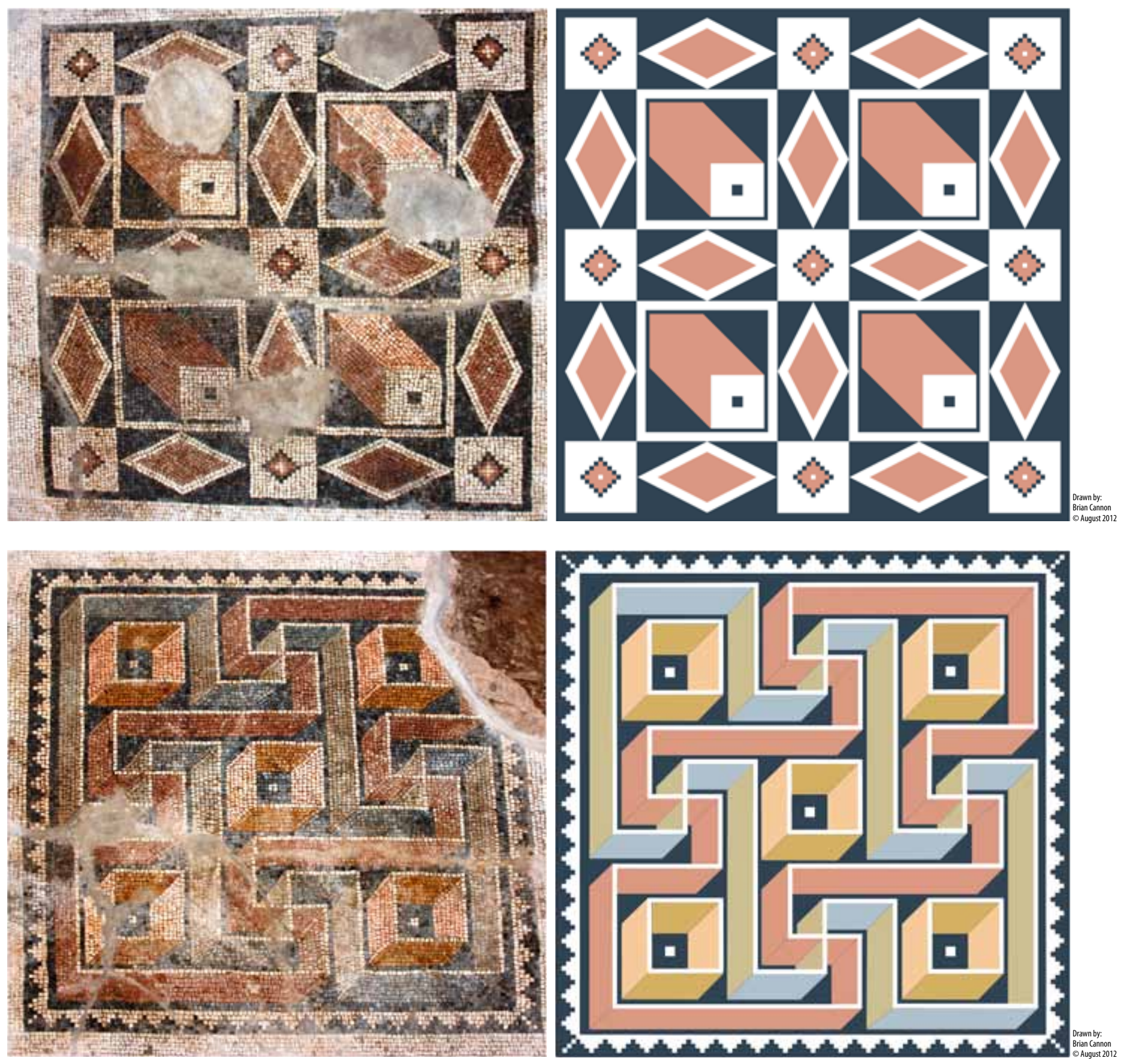

fig. 76-80 "Şanlıurfa Museum”; Önal 2009: fig. 2-3; Pamir 2015: 67 “Antioch,

Figure 11

House of Drunken Dionysos"). Panel E6 consists of alternating squares and recThe panel E6.

tangles (Fig. 11). The rectangles all have the same dimensions and elongated lozenges with white borders, while the squares have two different sizes. The

Figure 12 four central larger squares, similar to the elongated lozenges, have white borders The panel E7. and similar to Panel E4, squares with a three-dimensional appearance. Inside the smaller squares, connecting to the larger ones at the corners, are equilateral diamonds. A mosaic closely resembling Panel E6 is known from Antioch on the Orontes dating to the second century AD (Cimok 2000: 69 "Antioch, House of the Red Pavement"). The border of Panel E7 consists of a continuous, dark coloured, stepped triangle pattern (Fig. 12). It frames a labyrinth of meanders, three-dimensional in appearance, forming swastika motifs, a popular 

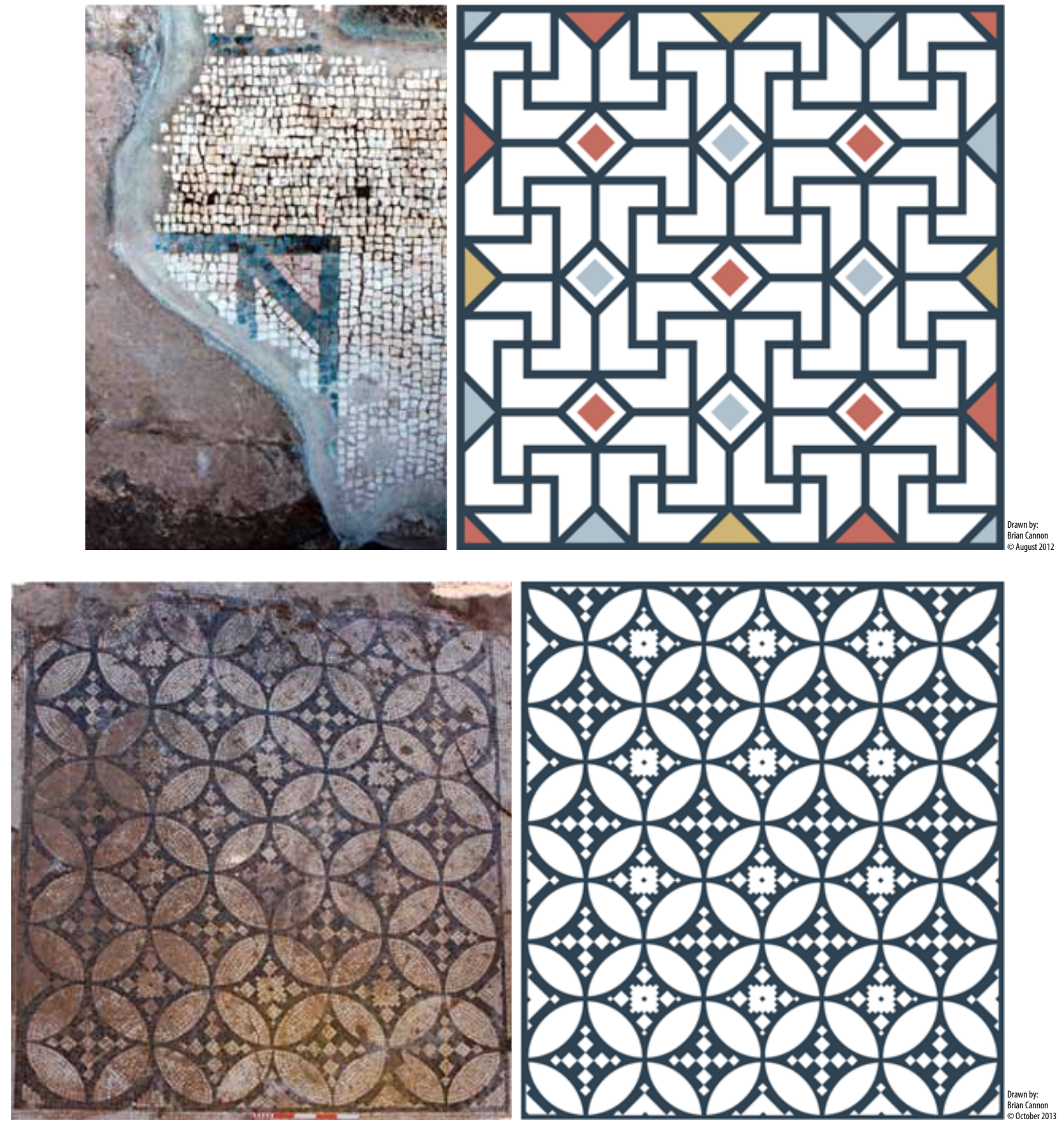

Figure 13

The panel E8.

Figure 14

The panel W1. motif in Roman mosaic art (Tülek 2005: fig. 11.18 "Hatay Museum, Oceanus and Tethys Mosaic", fig. 30.10, 30.12 "Elaiussa Sebaste, Agora"; Ergeç 2006: 66-67 “Zeugma, Villa of Maenad”, 100-107 “Zeugma, Villa of Poseidon”, 212215 "Zeugma, Achilleus Mosaic, Villa of Korintos"; Duran Kremer 2014: figs. 1, 6-7 “Zeugma, Villa of Poseidon", fig. 9 "Portugal-Rabaçal, Triclinium mosaic of a Roman Villa"). Swastika motifs in Panel E7 are very similar to those in a mosaic pavement in a house in Cilician Anemurium that dates to the first half of the fourth century AD (Campbell 1998: 4-5 pl. 18-19). Panel E8 is located at the southern end of the room and -apart from a small portion of its corner- is almost completely destroyed (Fig. 13). However, from this preserved corner, the mosaic appears to be similar to that in Panel E1. 

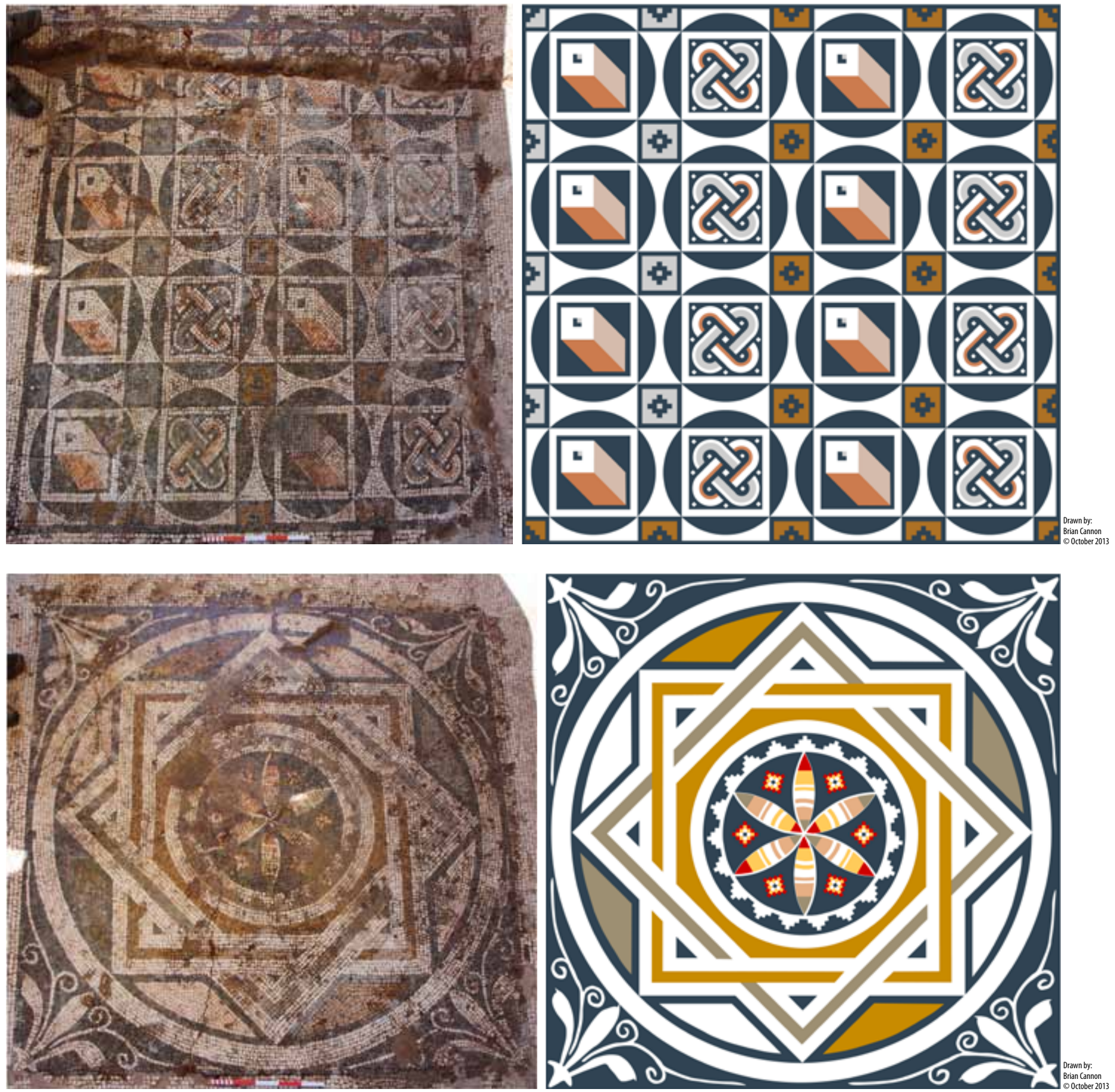

The northernmost of the eight mosaic panels to the west of the swimming pool, Panel W1, has a geometric design - similar to W7- consisting of intersect-

Figure 15 ing circles and, in between these as fillers, smaller diamond shapes (Fig. 14). The panel W2.

Intersecting circles forming quatrefoils are a very common motif in Cilicia (Campbell 1998: 60). Mosaics with very similar designs are known from Ephesos (Scheibelreiter 2008: figs. 3-4) and from Derecik (Fuchs - DelbarreThe panel W3. Bartschi 2011: fig. 5 "Bursa, Basilica of Derecik, Büyükorhan"), albeit belonging to later periods. In Panel W2 the design resembles Panel E4 on the east side of the pool; it features circles, squares and rectangles, Solomon's knots and cube motifs (Fig. 15). In Panel W3 the layout is composed of concentric circles and interlocking squares (Fig. 16). Square borders resembling those used in this 

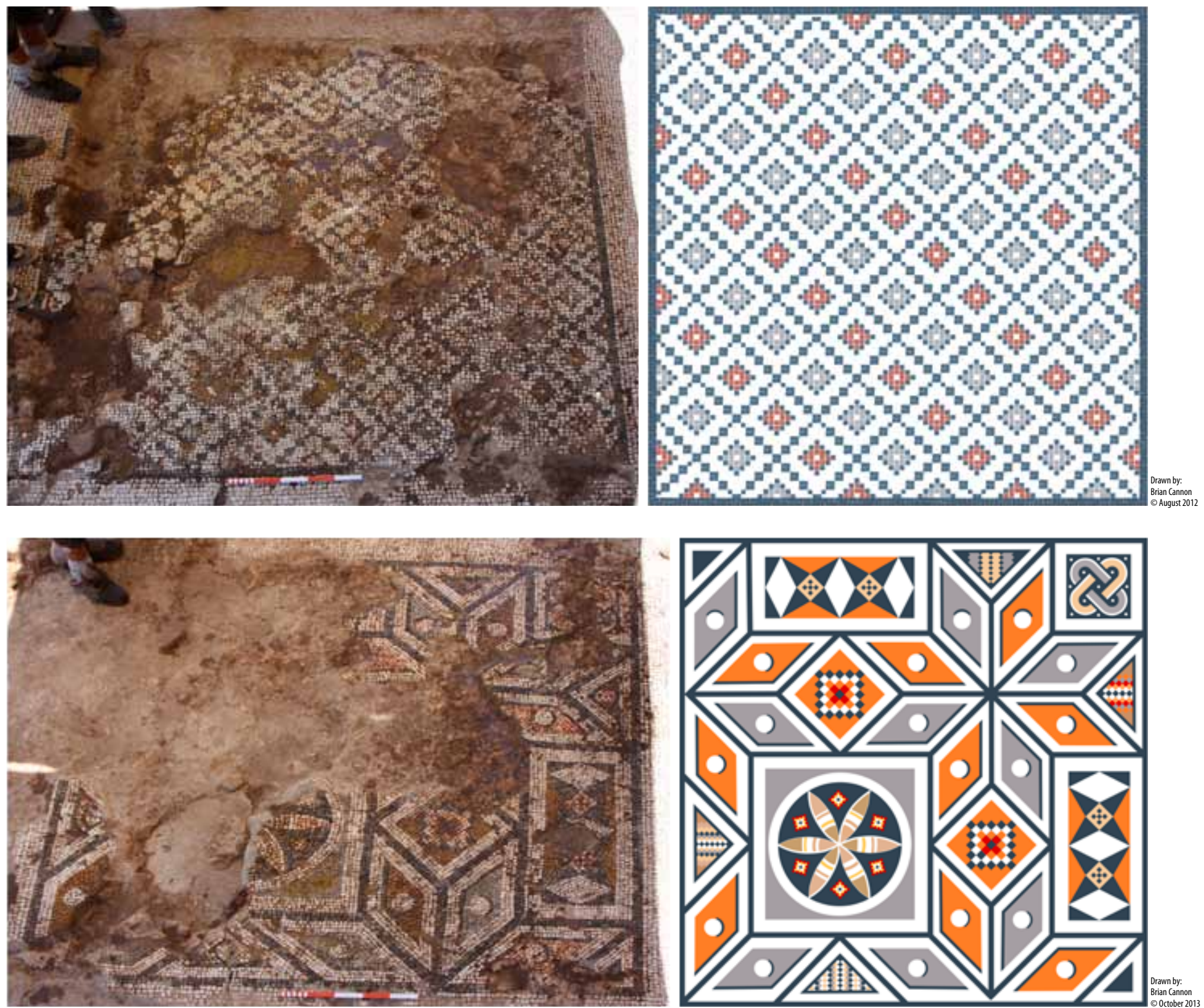

Figure 17

The panel W4.

Figure 18

The panel W5. panel have been encountered at numerous sites, mainly in Cilicia and the Iberian Peninsula, and in many variations (Campbell 1998: 27 pl. 129; Cimok 2000: 234 "Antioch, Soteria Mosaic, Bath of Apolausis"; Décor II: 89 figs. 288a-b; Tülek 2005: figs. 27.69 "Anemurium, The frigidarium of Large Bath", fig. 36.13 "Antioch"; Ergeç 2006: 172-175 "Zeugma, Ge Mosaic, Villa of Euphrates"; Blazquez 2008: fig. 14 "Spain, Soria, Villa Santervas del Burgo"; Wrench 2012: fig. 5 "Portugal, Conimbriga"; Wrench 2014: fig. 10 "Portugal, Bracara Augusta"; Belis 2016: 43-44 "Antioch, Soteria Mosaic, Bath of Apolausis") At the centre of this panel we see a stylized rosette-flower design with six multicoloured leaves. Between the leaves there are single, small diamonds. The rosette is a motif frequently used at the centre of panels of similarly decorated mosaics (Ergeç 2006: 52-53 “Zeugma, Villa of Dionysos"). In the corners of the panel are light coloured palmette and ornamental tendrils on a dark background. These corner elements are also quite common in similar mosaic panels (Cimok 2000: 103 “Antioch, House of the Red Porticos"; Ergeç 2006: 52-53 “Zeugma, Pasiphae and Daidalos Mosaic, Villa of Dionysos"). Panel W4 which is heavily damaged has the same grid motif as Panel E3 (Fig. 17). The middle of the square 

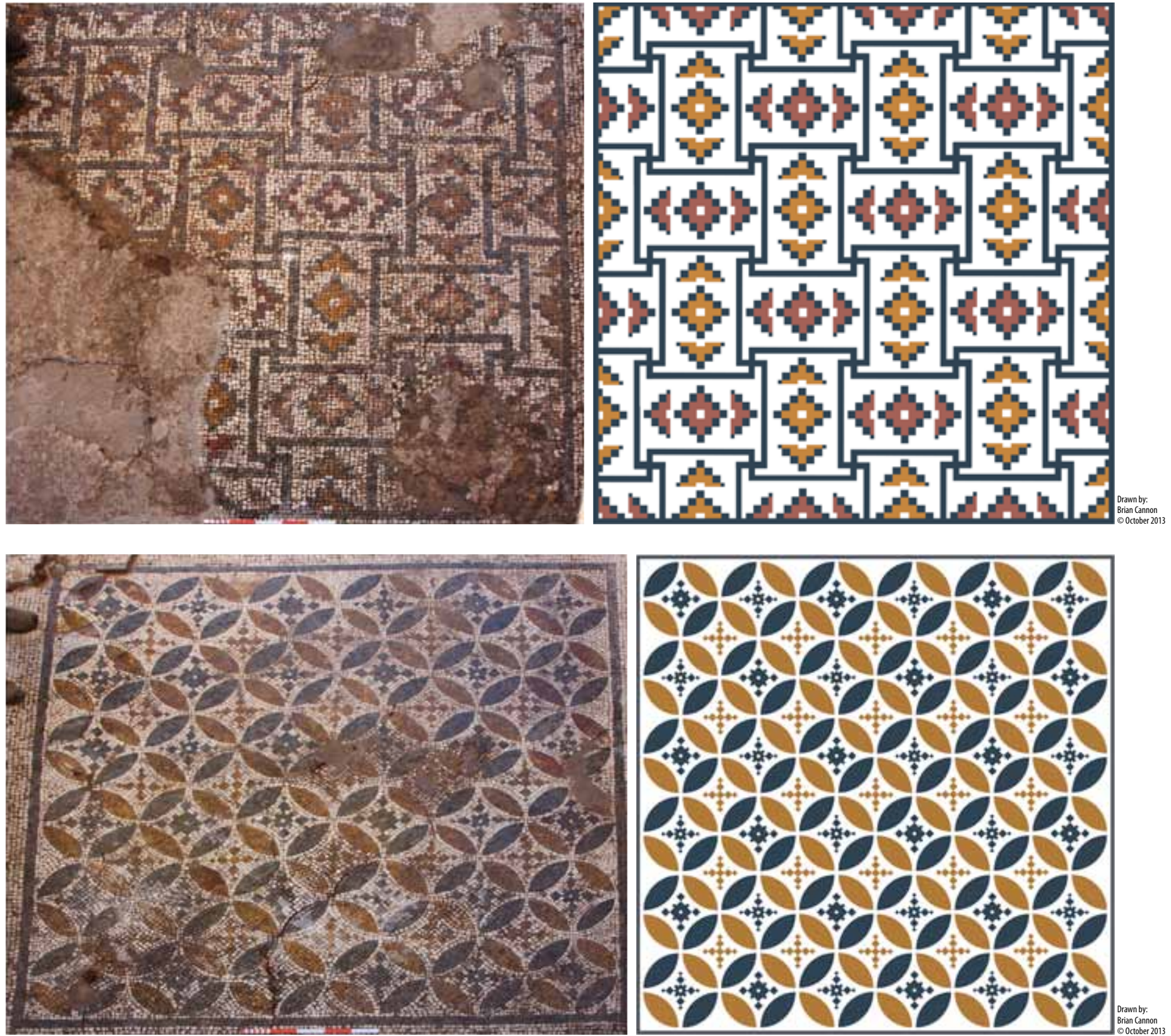

formations contain smaller and colourful diamond elements. Only half of Panel W5 is preserved (Fig. 18). This panel has a geometric design as well; it sets itself

Figure 19 apart from the other panels, however, in its lack of symmetry. An eight-pointed star and flower rosettes are the main decorative elements. Compared with other known examples (Kitzinger 1965: figs. 1-3 "Antioch, House of the Worcester Hunt"; Ling 1998: fig. 36 "Seleucia, House of the Drinking Contest"; Dunbabin 1999: fig. 167 "Seleucia, House of the Drinking Contest"; Cimok 2000: 124-125 "Antioch, House of Dionysus and Ariadne"; Parrish 2001: 342 fig. 20 "Kos, The Basilica of Hagios Stephanos"; Tülek 2005: fig. 20.7-8 "Hatay Museum, The Triptych Mosaic”; Ergeç 2006: 90-93 “Zeugma, Villa of Okeanos”, 104-107 "Zeugma, Villa of Dionysos"; Neuenfeldt 2009: 46 fig. 5 "Antioch, House of Dionysus and Ariadne"; Okçu 2009: fig. 1 "Bursa, Yerkapı"; Şen 2009: fig. 1824 "Allianoi"; Da Silva et al. 2011: figs. 9-10 "Portugal-Setubal, Caetobriga"; Duran Kremer 2011: figs. 9-11 "Portugal, Algarve, The Roman Villa of Abicada"; Romero - Vargas 2011: figs. 5-6 "Spain, Malaga, Antequera, Roman 

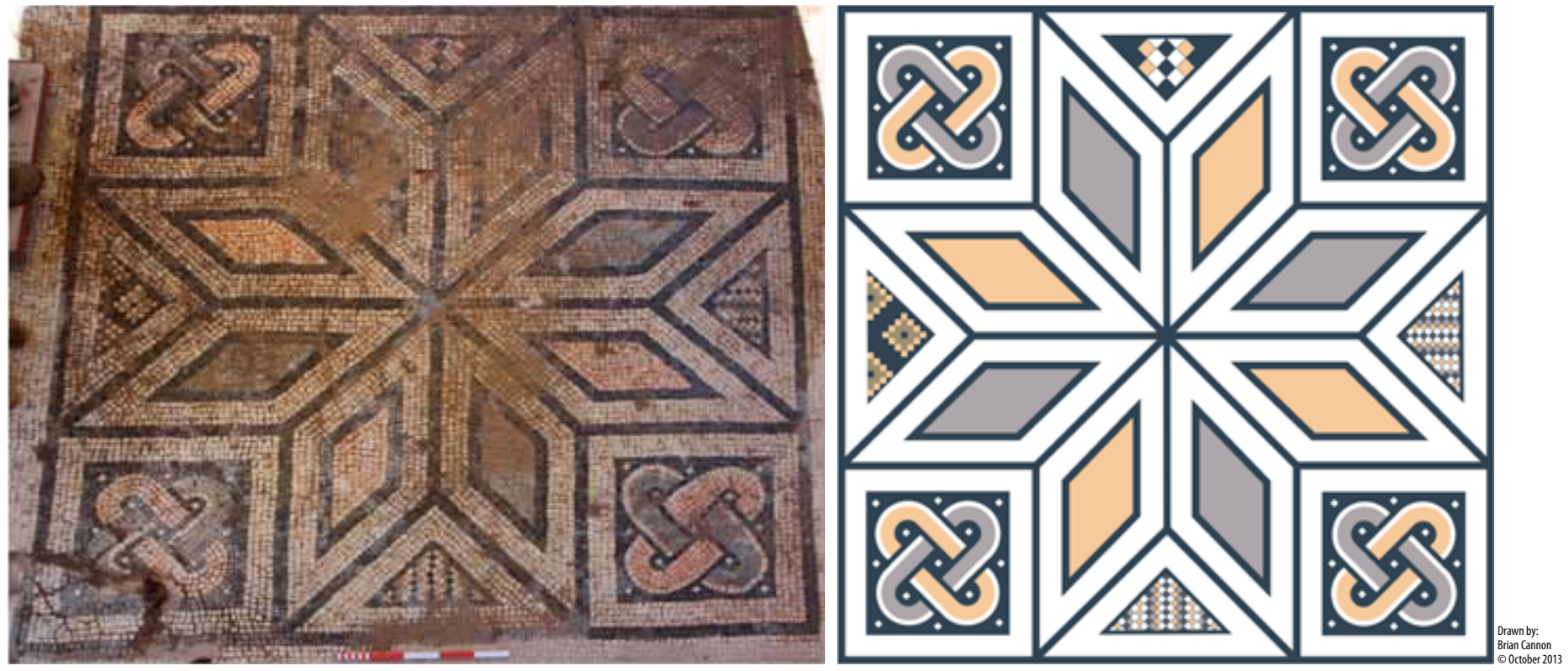

Figure 21

The panel W8.
Villa of Estacion"; Duran Kremer 2012: figs. 7 "Portugal, Cetobriga", fig. 13 "Portugal, Abicada", fig. 15 "Portugal, Milreu"; Duran Kremer 2014: figs. 6-7 "Zeugma, Villa of Poseidon"; Can 2015: 87 fig. 7 "Sukhumi/Sebastopolis, The Apodyterium of a Bath"; Pamir 2015: 68 "Antioch, House of Dionysus and Ariadne"), it is clear that this geometric motif was intended as a part of a symmetric and continuous pattern of a border or a larger panel. Yet in W5 its symmetry and integrity have been broken up in order to fit the limited size of the panel. Another damaged panel is Panel W6 (Fig. 19). Just as in E1, dark coloured linear bands run across the panel and intersect, forming a swastika motif. The rectangular spaces between contain colourful diamonds and half-diamonds. A similar pattern -apart from some differing details- can be seen in a border of a mosaic from Antioch on the Orontes dating to the early Byzantine period (Cimok 2000: 122 "Antioch, House of the Buffet Supper"). In Panel W7, we see the same geometrical construction of intersecting circles as in W1 (Fig. 20). The main difference is that the design of W7 is more colourful. The geometric layout and the colour combination of this motif also appears in the fourth century AD in the Seven Sages mosaic in the Villa de las Tiendas near Emerita Augusta, the capital of the province of Lusitania (Blazquez 2008: fig. 20). It is a frequent pattern in second and third century mosaics (Dunbabin 1999: fig. 153 “Augusta Emerita, House of Mithraeum"; Jobst 1999: 574 fig. 138.3 "Ephesos, Terrace House II"; Cimok 2000: 38-39 “Antioch, House of the Evil Eye"; Ergeç 2006: 48-49 "Zeugma, Villa of Dionysos", 136-139 “Zeugma, Eros and Psyche Mosaic, Villa of Poseidon"; Şahin 2007: 119-120 fig. 32 "Ephesos, Nereid and Triton Mosaic, Terrace House"; Tabanlı 2007: 50, 58 fig. 43, 54 "Ephesos, Terrace House"; Şen 2009: 21-25 fig. 12-16 “Allianoi”). In Panel W8, similar to W5, an eight-pointed star is located in the centre (Dunbabin 1999: 341), while Solomon's knot motifs are placed at the corners (Fig. 21). The star motif was also used in mosaics in Cilicia (Cimok 2000: 120 "Antioch, The Mosaic of Revellers and Hetaerae, House of the Buffet Supper", 124-125 "Antioch, House of Dionysus and Ariadne", 192-193 "Antioch, House of the Sun Dial”; Décor II: 98 pl. 296.a "Narlıkuyu”; Tülek 2005: figs. 1.5-7 "Misis Museum, Orpheus Mosaic", figs. 1.23-25 "Adana Museum”, figs. 1.26 "Apamea, The House of Pilasters", figs. 34.4 "Narlıkuyu, Bath of Poimenios"; Salman 2009: figs. 1-2 

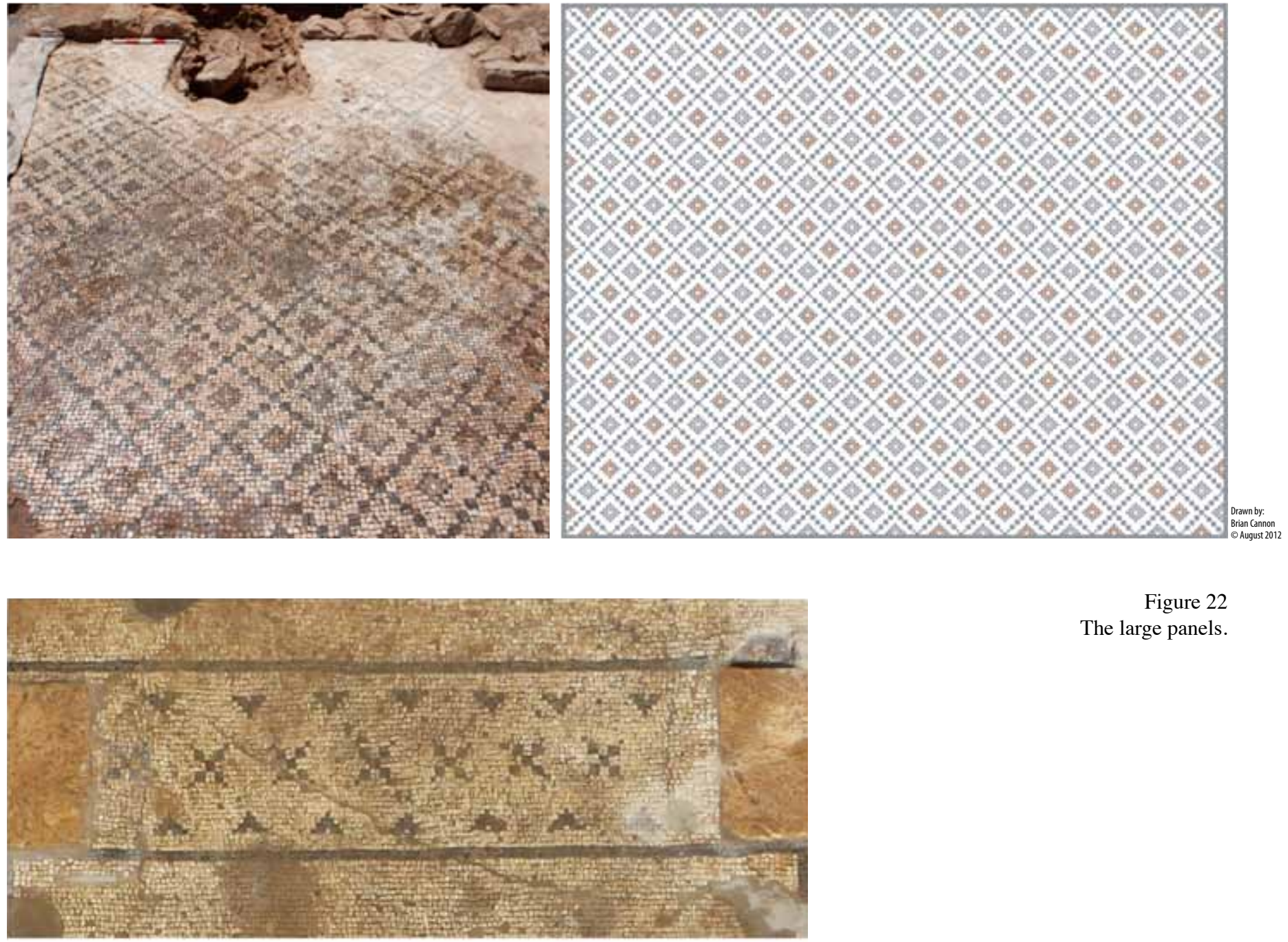

Figure 22

The large panels.

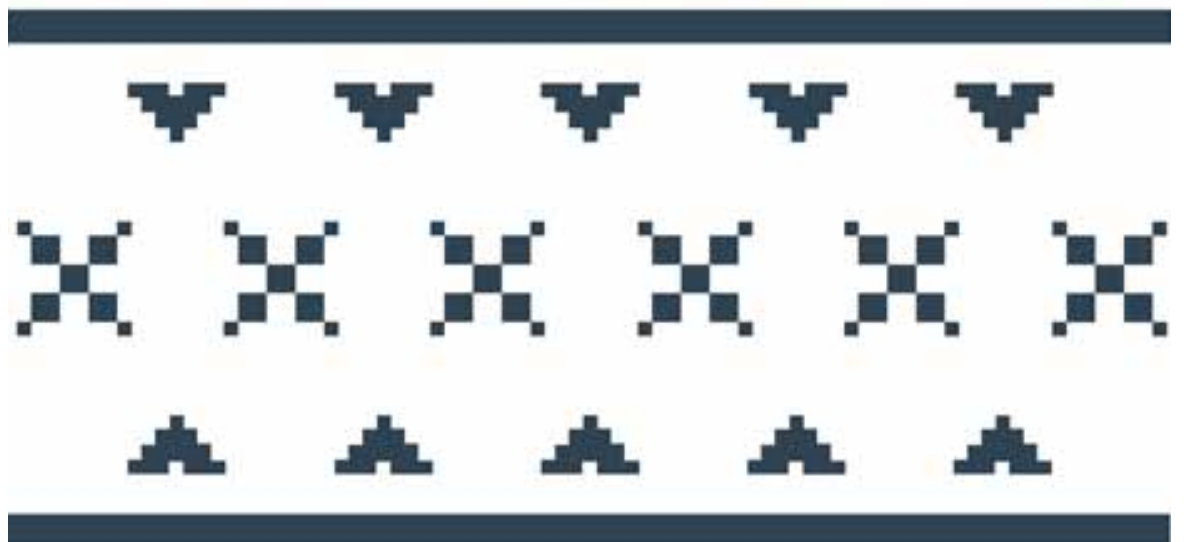

Figure 23

The borders between the column bases.

“Antioch, House of the Sun Dial”), Zeugma (Önal 2009: figs. 2-3) and Ionian Metropolis (Öz 2012: figs. 9, 14 "Metropolis, Roman Bath, South Portico of Palaestra").

In addition to these 16 square mosaic panels, in the large panels at the south and north of the pool concentric diamonds were placed diagonally to create a grid pattern similar to Panels E3 and W4 (Fig. 22). The exact same motif was used in the border of a mosaic depicting Bacchus and Satyr dating to the second and third centuries AD in Byblos, Lebanon (Chehab 1965: 334 fig. 2). It is also 
Figure 24

The northwest and northeast vestibules of the courtyard.

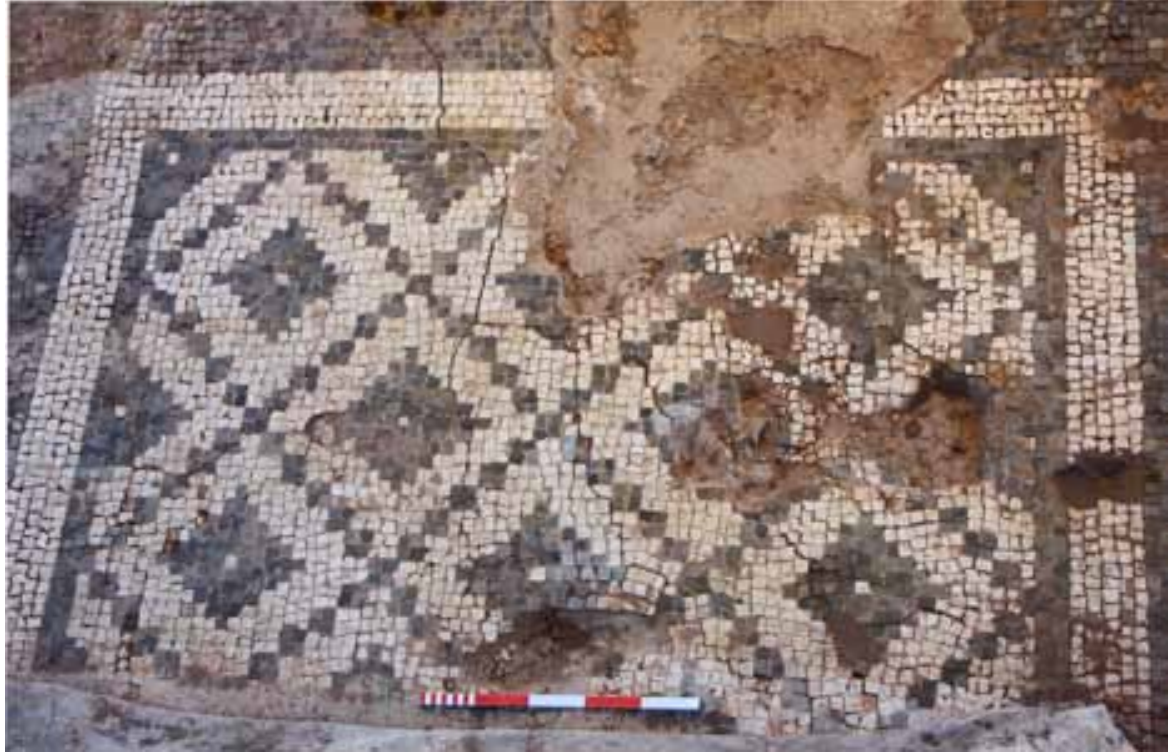

possible to see similar patterns in second to third century floor mosaics from Antioch on the Orontes and Zeugma (Cimok 2000: 54-55 "Antioch, House of Drunken Dionysos", 62 "Antioch, Comus Mosaic"; Ergeç 2006: 120-123 "Villa of Poseidon", 150-151 "Villa of Euphrates", 186-189 "Villa of Zosimos"; Pamir 2015: 73 "Antioch, House of Drunken Dionysos"). The exact same pattern can be found in the Exedra at Anemurium, dated to the second century AD, although the pattern colours are reversed (Campbell 1998: 13-14 pl. 54). The borders between the column bases consist of a simple geometric design of continuous " $\mathrm{X}$ " and "V" shapes formed by bluish-grey tesserae on a white background (Fig. 23). A small mosaic, matching the one by the entrance, is located right by the northern threshold of the courtyard. Resembling the patterns between the column bases, this mosaic is also composed of simple geometric motifs on a white background. Half-diamonds decorate the sides while full diamonds are lined along the middle.

It is assumed that the northeast entrance of the courtyard is the main entrance of the Bath complex from the Colonnaded Street. Here, a small vestibule has been built. A similar space can also be seen in the northwest of the courtyard. This symmetrical layout of these entrances is reflected in their floor mosaics, which are both decorated with the same geometric design (Fig. 24). However, these mosaics have been damaged more than the ones inside the courtyard and the dimensions of their tesserae are larger. The main design of these mosaics consists of a wide border made of dark tesserae and equilateral diamonds in the middle, lined up in diagonal rows. This is the same design as the ones seen in the large panels in the north and south of the courtyard pool. The tesserae used here are bluish grey and white in colour.

\section{Conclusion}

Since the very first civilisations, mathematics and especially geometry have played an important role structurally as well as aesthetically in architecture and many other aspects of human life. Apart from some exceptions, we observe that throughout architectural history buildings were constructed according to certain rules and principles. Foremost among these are symmetry, proportion and balance. They are consistently essential for architecture and structural engineering. 
Nevertheless, the same rules and principles also found use in the purely aesthetic elements of architecture such as geison, frieze, and column. This is especially evident in geometric combinations, as their design is not random and they have clearly been created according to certain symmetry, proportion and balance principles.

In the Great Bath complex of Antiochia ad Cragum we observe a geometric repertoire with many various shape and colour combinations. Examples of this kind of planned layout, consisting of borders and panels, are often found on the floors of large rooms (Dunbabin 1999: 75 fig. 75). The content of each panel also displays the same symmetry and order.

We observe that layouts of geometric mosaic panels are applied discreetly and non-discreetly. The non-discreet designs are continuous and if the panel is enlarged or elongated the core geometric motifs continue without change. But discreet motifs are consistent within themselves. With the Antiochia ad Cragum mosaics we observe the application of both of these practises. While most of the courtyard panels have non-discreet designs, Panel E7 with the three-dimensional swastika meander decoration, the elaborate squares and central six-leaved colourful flower in Panel W3, the eight-pointed star motif recurring in W5 and W8 are the discreet designs. Although some of these are part of a non-discreet extension. That said, geometric patterns in Panels E1, E6, and E8 resemble what is today known as Escher's infinite patterns.

The mosaics at the Great Bath complex of Antiochia ad Cragum possess a geometric repertoire that is consistent with other examples of Cilician mosaics. The geometric patterns seen in the panels on the courtyard floor were widely used from the end of the second century until the fourth century AD. In addition, finds such as coins and pottery uncovered during excavations from 2012 to 2015 indicate how long the building was in use. All data obtained by excavations and comparing other known examples, suggest the courtyard mosaics date to the third century AD (Can - Hoff 2014: 380; Previous studies dated the mosaics around the middle of the $3^{\text {rd }}$ century AD: Tülek 2005: 297-300 figs. 31.1-9). Previous studies dated the mosaics around the middle of the $3^{\text {rd }}$ century AD.

\section{Bibliography - Kaynaklar}

Abraços 2014

Belis 2016

Blazquez 2008

Campbell 1998

Can 2009

Can 2015

Can et al. 2015

Can et al. 2016
M. F. Abraços, "The Mosaics with Geometric Patterns from the West and the East of the Roman Empire: The Hourglass Pattern and the Significance of the "Le decor geometrique de la mosaique romaine I-II", JMR 7, 1-9.

A. Belis, Roman Mosaics in the J. Paul Getty Museum, J. Paul Getty Museum, Malibu, California.

J. M. Blazquez, "Der Einfluss der Mosaiken des vorderen Orients auf hispanische Mosaiken am Ende der Antike", JMR 1-2, 7-31.

S. Campbell, The Mosaic of Anemurium, Pontifical Institute of Mediaeval Studies, Toronto.

B. Can, "Erzincan Altıntepe Church with Mosaic", JMR 3, 5-13.

B. Can, "Analogical Observations on the Mosaics of the Caucasus and Anatolia”, M. Işıklı - B. Can (eds.), International Symposium on East Anatolia - South Caucasus Cultures, Proceedings II, Cambridge Scholars Publishing, 84-96.

B. Can - M. Hoff - R. Townsend - E. Erdoğmuş - T Howe, "The Antiochia ad Cragum Archaeological Research Project: 2014 Season", ANMED 13, 1-7.

B. Can - M. Hoff - D. Murphy, "Ancient Water Management Systems at Antiochia ad Cragum in Rough Cilicia”, De Aquaeductu Atque Aqua Urbium Lyciae Pamphyliae Pisidiae, The Legacy of Sextus Julius Frontinus, International Congress on the History of Water Management and Hydraulic Engineering in the Mediterranean Region, Antalya, October 31 - November 9, 2016, 79-91. 
Can - Hoff 2014

Chehab 1965

Cimok 2000

Çelik 2008

Da Silva et al. 2011

Décor II

Dunbabin 1999

Duran Kremer 2011

Duran Kremer 2012

Duran Kremer 2014

Ergeç 2006

Fuchs - Delbarre-Bartschi 2011

M. E. Fuchs - S. Delbarre-Bärtschi, "Derecik, Büyükorhan, Une église pour deux mosaïques”, M. Şahin (ed.), $11^{\text {th }}$ International Colloquium on Ancient Mosaics, October $16^{\text {th }}-20^{\text {th }}, 2009$, Bursa-Turkey, İstanbul, 405-412.

Hoff - Can 2013

Hoff et al. 2013a

Hoff et al. 2013b

Hoff et al. 2014a

Hoff et al. 2014b

Hoff et al. 2015a

Hoff et al. 2015b

Houix et al. 2011

Jobst 1999

Jobst 2011

Kitzinger 1965

Ling 1998

Neuenfeldt 2009

B. Can - M. Hoff, “Antiochia ad Cragum, Batı Dağlık Kilikya'da Bir Roma Kenti ve Kazıları”, H. Kasapoğlu - M. A. Y1lmaz (eds.), Anadolu'nun Zirvesinde Türk Arkeolojisinin 40 Y1lı, Ankara, 373-392.

M. Chehab, "Les Caracteristiques de la mosaique au Liban", CMGR I, 333-339.

F. Cimok, Antioch Mosaics: A Corpus, İstanbul.

Ö. Çelik, "2006 Yılı Hatay Müzesi Mozaik Kurtarma Kazıları”, M. Şahin (ed.), The Proceedings of IV. International Mosaic Corpus of Türkiye: The Mosaic Bridge from Past to Present, 6-10 June 2007, Gaziantep, 27-33.

C. T. da Silva - J. Soares - L. Nunes Correia Wrench, "Les premieres mosaïques romaines découvertes á Caetobriga (Setubal, Portugal)", M. Şahin (ed.), $11^{\text {th }}$ International Colloquium on Ancient Mosaics, October $16^{\text {th }}-20^{\text {th }}, 2009$, Bursa-Turkey, İstanbul, 295-308.

C. Balmelle - M. Blanchard Lemée - J. P. Darmon - S. Gozlan - M. P. Raynaud, Le Décor Géométrique De La Mosaïque Romaine II, Paris, 2002.

K. M. D. Dunbabin, Mosaics of the Greek and Roman World, Cambridge.

M. J. Duran Kremer, "Les mosaiques geometriques de la villa romaine de Abicada: leur rôle dans le contexte des mosaïques romaines de l'Algarve", M. Şahin (ed.), $11^{\text {th }}$ International Colloquium on Ancient Mosaics, October $16^{\text {th }}-20^{\text {th }}, 2009$, Bursa-Turkey, İstanbul, 353-361.

M.J. Duran Kremer, "Floral and Geometrical Motives of the Pavement Mosaics in East and West. The Examples of the Roman Villa of Abicada", JMR 5, 59-70.

M. J. Duran Kremer, "East Meets West: The Perspective in Roman Mosaics", JMR 7, 25-34.

R. Ergeç, Belkıs - Zeugma ve Mozaikleri, İstanbul.

M. Hoff - B. Can, “Antiocheia, Korsanların Kenti / The City of Pirates”, Antalya Culture \& Tourism Magazine $17,46-52$.

M. Hoff - R. F. Townsend - B. Can, "The Antiochia ad Cragum Archaeological Research Project: 2012 Season", ANMED 11, 154-163.

M. Hoff - R. Townsend - E. Erdoğmuş - B. Can, “The Antiochia ad Cragum Archaeological Research Project: 2012 Season", 35. KST 3, 465-481.

M. Hoff - R. Townsend - E. Erdoğmuş - B. Can, "Antiochia ad Cragum: Excavation of a Roman era City in Western Rough Cilicia”, Journal of Archaeology and Art 145, 65-74.

M. Hoff - R. Townsend - B. Can - E. Erdoğmuş, "The Antiochia ad Cragum Archaeological Research Project in 2013", ANMED 12, 6-13.

M. Hoff - R. Townsend - E. Erdoğmuş - B. Can - T. Howe, "Antiochia ad Cragum in Western Rough Cilicia", S. R. Steadman - G. McMahon (eds.), The Archaeology of Anatolia: Current Work (2013-2014), Cambridge Scholars Publishing, 204-229.

M. Hoff - B. Can - R. Townsend - E. Erdoğmuş - T. Howe, "The Antiochia ad Cragum Archaeological Research Project: 2014 Season", 37. KST. 3, 581-594.

B. Houix - V. Blanc-Bijon - J. Y. Breuil - J. P. Darmon - P. Linant de Bellefonds, "Mosaiques a themes mythologiques recemment decouvertes sous l'avenue Jean-Jaures a Nimes (France)”, M. Şahin (ed.), $11^{\text {th }}$ International Colloquium on Ancient Mosaics, October $16^{\text {th }}-20^{\text {th }}, 2009$, Bursa-Turkey, İstanbul, 447-465.

W. Jobst, “Antike Tessellatpavimente in Ephesos”, H. Friesinger - F. Krinzinger (eds.), 100 Jahre Österreichische Forschungen in Ephesos, Akten des Symposions Wien 1995, 569-580.

W. Jobst, "Das Mosaikpaviment der frühchristlichen Basilika von Gönen/Germe in Mysien (Hellespont)", M. Şahin (ed.), 11th. International Colloquium on Ancient Mosaics, October $16^{\text {th }}-20^{\text {th }}, 2009$, Bursa-Turkey, İstanbul, 483-504.

F. Kitzinger, "Stylistic Developments in Pavement Mosaics in the Greek East from the Age of Constantine to the Age of Justinian", CMGR I, 341-352.

R. Ling, Ancient Mosaics, London.

L. P. Neuenfeldt, Eros and Erotes in the Late Antique Mosaics of Antioch, Unpublished MA Thesis, Florida State University. 
Okçu 2009

Omari 2011

Ovadiah 1980

Önal 2009

Öz 2012

Pamir 2015

Parrish 2001

Patacı 2011

Romero - Vargas 2011

Salman 2007

Salman 2009

Scheibelreiter 2008

Şahin 2007

Şen 2009

Tabanlı 2007

Tülek 2005

Wrench 2012

Wrench 2014
R. Okçu, "Prusia ad Olympum Mozaikleri", JMR 3, 31-51.

E. Omari, "The History and Development of Mosaics in Albania ( $4^{\text {th }} / 3^{\text {rd }}$ Century B.C. $-6^{\text {th }}$ Century A.D.)", M. Şahin (ed.), $11^{\text {th }}$ International Colloquium on Ancient Mosaics, October $16^{\text {th }}-20^{\text {th }}$, 2009, Bursa-Turkey, İstanbul, 675-691.

A. Ovadiah, Geometric and Floral Patterns in Ancient Mosaics. A Study of Their Origin in the Mosaics from the Classical Period to the Age of Augustus, Rome.

M. Önal, “Danae Evi'nin Mozaikleri”, JMR 3, 53-69.

A. K. Öz, "The Research and Conservation Study of the Mosaics of the Roman Bath at Metropolis", JMR 5, 145-161.

H. Pamir, "Antioch Mosaics”, Actual Archaeology Magazine 14, 62-73.

D. Parrish, "An Early Byzantine Mosaic Workshop Based on Kos: Architectural Context and Pavement Design", Antiquite Tardiva 9, 331-349.

S. Patac1, "Paphlagonia Hadrianoupolis'i Hamam A ve A Kilisesi Mozaikleri”, JMR 4, 27-50.

M. Romero - S. Vargas, "Mosaic Workshop Located in the Villa de la Estacion de Antequera, Malaga (Espana)", M. Şahin (ed.), $11^{\text {th }}$ International Colloquium on Ancient Mosaics, October $16^{\text {th }}-20^{\text {th }}, 2009$, Bursa-Turkey, İstanbul, 823-828.

B. Salman, Orta Euphrates Mozaikleri Işı̆̆ında Edessa ve Samosata Mozaikleri, Yayınlanmamış Doktora Tezi, Dokuz Eylül Üniversitesi, İzmir.

B. Salman, "Mozaikler Üzerinde Güneş Saati Betimli Sahneler”, JMR 3, 83-93.

V. Scheibelreiter, "Gold from Ephesus: The Evidence of a Dionysus-Mosaic in Terrace House 2", M. Şahin (ed.), The Proceedings of IV. International Mosaic Corpus of Türkiye: The Mosaic Bridge from Past to Present, 6-10 June 2007, Gaziantep, 141-146.

D. Şahin, Roma Dönemi Mozaik Betilerine Göre Nereid İkonografisi, Yayınlanmamış Doktora Tezi, Selçuk Üniversitesi, Konya.

Ö. Şen, Allianoi Ilıcası Taban Mozaikleri, Yayınlanmamış Yüksek Lisans Tezi, Trakya Üniversitesi, Edirne.

D. Tabanlı, Roma Dönemi Mozaiklerinin Efes Örneğinde İncelenmesi, Yayınlanmamış Yüksek Lisans Tezi, Dokuz Eylül Üniversitesi, İzmir.

F. Tülek, Late Roman and Early Byzantine Floor Mosaics in Cilicia, Unpublished Dissertation, University of Illinois.

L. N. C. Wrench, "Exemples du decor vegetal en quelques mosaïques romaines: Du Portugal a l'autre extreme de la Mediterranee", JMR 5, 225-234.

L. N. C. Wrench, "Some Geometrical Patterns and Decorative Motifs Occuring in Roman Portuguese Mosaics: A Comparative Approach with Eastern and Western Mosaics", JMR 7, 49-59. 